\title{
Effects of treatment with Astragalus Membranaceus on function of rat leydig cells

Xiaolong Jiang ${ }^{1 \dagger}$, Xia Cao ${ }^{1 \dagger}$, Yang Huang ${ }^{1}$, Jianwei Chen ${ }^{1}$, Xiaolei Yao ${ }^{1}$, Miaomiao Zhao ${ }^{1}$, Yan Liu' ${ }^{1}$, Jinzhu Meng ${ }^{1}$, Pengfei Li ${ }^{2}$, Zhiyan $\mathrm{Li}^{3}$, Jianbo Yao ${ }^{1,7}$, George W Smith ${ }^{1,4,5,6}$ and Lihua Lv' ${ }^{1 *}$

\begin{abstract}
Background: Astragalus membranaceus (AM) is a Chinese traditional herb which has been reported to have broad positive effects on many diseases, including hepatitis, heart disease, diabetes and skin disease. AM can promote cell proliferation, increase the activities of superoxide dismutase (SOD) and glutathione peroxidase (GPx), and inhibit apoptosis by regulating the transcription of proto-oncogenes controlling cell death. While AM is included in some commercially available "testosterone boosting supplements", studies directly testing ability of AM to modulate testosterone production are lacking. In the present study, we examined the effects of AM on Leydig cell function in vitro.
\end{abstract}

Methods: Rat Leydig cells were purified and treated with $A M$ at different concentrations $(0 \mu \mathrm{g} / \mathrm{mL}, 10 \mu \mathrm{g} / \mathrm{mL}$, $20 \mu \mathrm{g} / \mathrm{mL}, 50 \mu \mathrm{g} / \mathrm{mL}, 100 \mu \mathrm{g} / \mathrm{mL}$ and $150 \mu \mathrm{g} / \mathrm{mL}$ ) and cell counting-8 (CCK-8) assay, Enzyme-linked immunosorbent assay, quantitative real time PCR and analysis of activities of SOD and GPx were done respectively.

Results: Treatment with $100 \mu \mathrm{g} / \mathrm{mL}(P<0.05)$ and $150 \mu \mathrm{g} / \mathrm{mL} A M(P<0.01)$ significantly increased Leydig cell numbers. Treatment with $A M(20 \mu \mathrm{g} / \mathrm{mL}, 50 \mu \mathrm{g} / \mathrm{mL}$ and $100 \mu \mathrm{g} / \mathrm{mL})$ significantly increased testosterone production $(P<0.01)$. In addition, increased Leydig cell SOD and GPx activities were observed in response to $20 \mu \mathrm{g} / \mathrm{mL}$ and $50 \mu \mathrm{g} / \mathrm{mL}$ AM treatment $(P<0.01)$. Furthermore, expression of Bax mRNA was significantly decreased $(P<0.01)$, and the ratio of $B C l-2 / B a x$ mRNA was significantly increased in response to $20 \mu \mathrm{g} / \mathrm{mL} A M$ in the culture medium $(P<0.05)$.

Conclusions: Results supported a beneficial effect of $A M$ on multiple aspects of rat Leydig cell function in vitro including testosterone production.

Keywords: Astragalus membranaceus, Leydig cell, SOD and GPx, Bax, BCl-2, Testosterone

\section{Background}

Astragalus membranaceus (AM), a well-known Chinese medicinal plant, has been widely used as a traditional prescription medicine for treatment of various diseases, including hepatitis [1], diabetic nephropathy [2,3], cardiovascular disorders $[4,5]$ and skin diseases [6]. $A M$ has various favorable pharmacological effects including antifibrotic [1, 7-9], anti-oxidant [10], anti-apoptotic [11], anti-inflammatory [12] and immune-enhancing properties [13]. $A M$ inhibits apoptosis mainly by regulating the expression of $B a x$ and $B c l-2$, members of the $B$ cell leukemia protein $(\mathrm{Bcl})-2$ family that controls the intrinsic apoptotic

\footnotetext{
*Correspondence: lihualvsxau@126.com

${ }^{\dagger}$ Equal contributors

${ }^{1}$ College of Animal Science and Technology, Shanxi Agricultural University, No.1 Mingxian Nan Road, Taigu 030801, China

Full list of author information is available at the end of the article
}

pathway [14]. A previous study has shown that glucoseinduced podocyte apoptosis was inhibited by intravenous $A M$ injection in vivo and $A M$ treatment in vitro with effects linked to down regulation of Bax expression and up-regulation of $B c l-2$ expression [15]. Collectively, these observations indicate that $A M$ has therapeutic effects in the context of various types of disease.

Although numerous studies support potential medicinal value of $A M$, its effects on the reproductive system have not been well investigated. Limited studies have demonstrated effects of $A M$ on the motility of human spermatozoa in vitro [16] and amelioration of reproductive toxicity induced by cyclophosphamide in male mice [17] and sperm abnormalities in cadmium-treated rats [18]. Hong et al. tested effects of 18 types of Chinese herbs on semen parameters and only $A M$ aqueous 
extract showed a significant stimulatory effect on the motility of human spermatozoa [16].

Leydig cells are distributed in the loose connective tissue between the seminiferous tubules, accounting for $2 \%-4 \%$ of testicular cells. Their main physiological function is to produce testosterone. Adult Leydig cells secrete testosterone required for the onset and maintenance of spermatogenesis [19]. However, studies directly testing effects of $A M$ on Leydig cells and ability of $A M$ to modulate testosterone production are lacking.

In the present study, we examined the effects of $A M$ injection on rat Leydig cells, which supported a stimulatory effect on multiple aspects of rat Leydig cell function in vitro.

\section{Methods}

Materials All materials were obtained from Huaxia Biotech (Beijing, China) unless stated otherwise.

Animals Healthy male rats $(\mathrm{n}=3)$ with average weight of 280-300 grams at 50-60 days of age were obtained from the Central Animal Services, Fudan University. Animals were euthanized by $\mathrm{CO}_{2}$ inhalation followed by cervical dislocation. All animal procedures were performed with approval of the Fudan University institutional animal care and use committee and in conformity with the guidelines for the care and use of laboratory animals formulated by the Ministry and Science and Technology of China (The Ministry and Science and Technology of the People's Republic of China, Beijing, China, 2006).

$A M$ solution preparation $A M$ injection was purchased from Wu Jing Hospital (Shanghai, China), and each was loaded $100 \mathrm{~mL}$ which was equivalent to 20 grams of raw herb. $A M$ injection was diluted in dimethyl sulfoxide (DMSO) (Sigma, Shanghai, China) at $10 \mu \mathrm{g} / \mathrm{mL}, 20 \mu \mathrm{g} /$ $\mathrm{mL}, 50 \mu \mathrm{g} / \mathrm{mL}, 100 \mu \mathrm{g} / \mathrm{mL}$ and $150 \mu \mathrm{g} / \mathrm{mL}$ respectively for cell culture.

Isolation and purification of rat Leydig cells Testes were excised sterilely from male rats $(n=3)$ following euthanasia and placed in PBS (pH 7.0-7.2). After washing 2 times with PBS, the testes were placed in DMEM. After removing the epididymis, fat and tunica albuginea, the testes were shredded into small pieces and transferred to a 50 $\mathrm{mL}$ centrifuge tube containing DMEM. Leydig cells were dispersed by pipetting followed by centrifugation at 800 rpm for $10 \mathrm{~min}$ at $4{ }^{\circ} \mathrm{C}$. Pellet was resuspended in medium followed by centrifugation twice at $600 \mathrm{rpm}$ and $4{ }^{\circ} \mathrm{C}$ for 2 min. Supernatant was collected and the cells were seeded into culture dishes for $12 \mathrm{~h}$ at $37{ }^{\circ} \mathrm{C}$ with $5 \% \mathrm{CO}_{2}$. Culture medium was then replaced and cells cultured for another $12 \mathrm{~h}$ with Leydig cell purity assessed as described below.

$3 \beta$-hydroxysteroid dehydrogenase ( $3 \beta$-HSD) staining The purity of cells was determined by $3 \beta$-HSD staining. After above described $24 \mathrm{~h}$ culture, media was removed and cells were removed from culture dish and placed in suspension. The Leydig cell suspension was incubated for $1 \mathrm{~h}$ at $37{ }^{\circ} \mathrm{C}$ with $1 \mathrm{mg} / \mathrm{mL}$ NBT (nitroblue tetrazolium), 3 $\mathrm{mg} / \mathrm{mL} \mathrm{NAD}^{+}$(Nicotinamide Adenine Dinucleotide), 2 $\mathrm{mg} / \mathrm{mL}$ DHEA (dehydroepiandrosterone) and $1.6 \mathrm{mg} / \mathrm{mL}$ nicotinamide in 0.1 M PBS (Phosphate Buffered Saline). Stained cells were washed with PBS once and fixed in 10 $\%$ formaldehyde - $50 \%$ ethanol ( $\mathrm{v} / \mathrm{v})$ for $30 \mathrm{~min}$, after which the cells were sedimented and washed two times. A drop of resuspended cell suspension was placed on a glass microscope slide. After drying, the percent of positive cells with a distinct blue reaction product were observed under a microscope (Olympus, Hong Kong, China).

Culture of Leydig cells and AM treatment Purified Leydig cells were seeded in either 96-well culture plates $(3 \times$ $10^{3}$ cells/well $)$ or 24 -well culture plates $\left(2 \times 10^{4}\right.$ cells/well $)$ and cultured in $90 \%$ DMEM plus $10 \%$ FBS and $1 \%$ Penicillin-Streptomycin solution at $37{ }^{\circ} \mathrm{C}$ and $5 \% \mathrm{CO}_{2}$. Treatments consisted of culture medium without (control group with equivalent DMSO instead of $A M$ injection) or with different concentrations of $A M$ injection $(10 \mu \mathrm{g} / \mathrm{mL}$, $20 \mu \mathrm{g} / \mathrm{mL}, 50 \mu \mathrm{g} / \mathrm{mL}, 100 \mu \mathrm{g} / \mathrm{mL}, 150 \mu \mathrm{g} / \mathrm{mL}) .48 \mathrm{~h}$ after treatment, the cells and/or culture medium were collected and used in various assays described below. All experiments were repeated 3 times using testes obtained from different rats on different days.

Cell proliferation assay Cell proliferation was detected using a CCK-8 (cell counting kit-8) assay kit according to the manufacturer's instructions (Dojindo, Shanghai, China). After above described $48 \mathrm{~h}$ culture, the culture medium was collected and Leydig cells were washed two times with $0.1 \mathrm{M}$ PBS. Then $10 \mu \mathrm{L}$ of CCK- 8 reagent was added to each well and incubated at $37^{\circ} \mathrm{C}$ for $2 \mathrm{~h}$. The WST-8 (2 - (2 - methoxy - 4 - (phenyl) - 3 - (4 - (phenyl) - 5 - (2, 4 - sulpho benzene) - $2 \mathrm{H}$ - tetrazolium monosodium salt) in the reagent can be reduced to orange-yellow formazan by dehydrogenase, which is proportional to the number of viable cells. Absorbance at $450 \mathrm{~nm}$ was recorded using a microplate reader (Thermo Scientific, Shanghai, China). A standard curve was designed using Leydig cell suspension with different dilution rates to calculate the viable cell numbers in each sample.

Testosterone Enzyme-Linked Immunosorbent assay (ELISA) Concentrations of testosterone in culture medium were detected using a Rat Free testosterone ELISA kit following the manufacturer's instructions (Zhongtianjingwei Science and Technology Co., LTD, Beijing, China). The ELISA plates were read with a microplate reader (Thermo Scientific, Shanghai, China) to record the optical densities and testosterone concentrations derived from standard curve.

Assays for SOD and GPx activities After removing the medium, Leydig cells were suspended in $10 \mathrm{mM}$ PBS (pH 7.0-7.2, $\quad 100-200 \mu \mathrm{L} / 10^{6}$ cells) and cells lysed via homogenization. The mixture was centrifuged at 4,000 rpm for $10 \mathrm{~min}$ at $4{ }^{\circ} \mathrm{C}$ and supernatants $(20-100 \mu \mathrm{g}$ protein per sample according to the reagent specification) 
used for measurement of activity of SOD and GPx using the Total Superoxide Dismutase Assay kit (Jiancheng Bioengineering Institute, Nanjing, China) with WST-8 and Cellular Glutathione Peroxidase Assay Kit respectively (Jiancheng Bioengineering Institute, Nanjing, China). The activity of SOD and GPx was adjusted according to the protein concentrations in different samples.

Quantitative real time PCR Total RNA was isolated from the Leydig cell lysates using the miRNeasy mini kit following the manufacturer's protocol (Qiagen, Shanghai, China). The integrity and concentration of total RNA were measured by agarose gel electrophoresis and Nanodrop-1000 spectrophotometer (Gene Company Limited, Hongkong, China), respectively. Total RNA (500 $\mathrm{ng} /$ sample) was then converted to cDNA using the iScript cDNA synthesis kit following the manufacturer's instructions (Thermo Scientific, Shanghai, China). cDNA was diluted using nuclease free water to a final volume of $40 \mu \mathrm{L}$.

Quantitative real time PCR (qRT-PCR) was performed using a $20 \mu \mathrm{L}$ reaction volume containing $10 \mu \mathrm{L}$ of SYBR ${ }^{\circ}$ premix Ex Taq $q^{\text {tm }}$ II(Ruian Biotech., Shanghai, China), 0.4 of ROX Reference Dye II, $0.8 \mu \mathrm{L}$ each of forward and reverse primer, $2 \mu \mathrm{L}$ of cDNA and $6 \mu \mathrm{L}$ of nuclease free water. Reactions were run on a 7500 Real Time PCR system (Thermo Scientific, Beijing, China) for 45 cycles of $95{ }^{\circ} \mathrm{C}$ for $15 \mathrm{~s}$ followed by $60{ }^{\circ} \mathrm{C}$ for $1 \mathrm{~min}$. GAPDH gene was used as the endogenous control. Primers were designed using Primer 3 (http://primer3.ut.ee/). The primers were as follows: GAPDH, 5' - TGGGTGTGAACCACGAGA -3' (forward) and 5'-GGCATGGACTGTGGTCATGA -3 (reverse); Bax, 5' - AGGATGCGTCCACCAAGAAGC -3' (forward) and 5'-CGGAAGAAGACCTCTCGGGG-3' (reverse); Bcl-2, 5' - GGAGCGTCAACAGGGAGATG-3' (forward) and 5' - CAGCCAGGAGAAATCAAACAGA $-3^{\prime}$ (reverse). The relative mRNA expression level of $B a x$ and $B c l-2$ was calculated using the comparative $2^{-\Delta \Delta C T}$ method [20]. Here, we chose $20 \mu \mathrm{g} / \mathrm{mL} A M$ as the treatment, because the results of preliminary test indicated that $A M$ in concentration of $20 \mu \mathrm{g} / \mathrm{mL}$ can significantly improve the biological function of Leydig cells, and the concentration is more economical in a real application.

Statistical analysis All data were analyzed in one way ANOVA using SPSS computer software (IBM, USA). Effects of $A M$ treatment (control versus $20 \mu \mathrm{g} / \mathrm{mL} A M$ ) on $B c l-2$ and Bax mRNA were analyzed by Student's $t$-test. Means were separated using Tukey's test. Data are presented as mean \pm SE.

\section{Results}

Leydig cell purity To assess the purity of cultured Leydig cells, $3 \beta$-HSD staining was performed. The results showed that the purity of cultured Leydig cells was $>95 \%$ (Fig. 1).

AM treatment increased Leydig cell numbers To investigate the effect of $A M$ injection on Leydig cells, numbers of viable cells were determined by CCK- 8 assay 48 $\mathrm{h}$ after $A M$ treatment. Compared with the untreated control, numbers of viable cells increased within a certain range of concentration, particularly at the concentrations of $100 \mu \mathrm{g} / \mathrm{mL}(P<0.05)$ and $150 \mu \mathrm{g} / \mathrm{mL}(P<0.01)$ (Fig. 2$)$. The result suggested that addition of $A M$ increases numbers of viable Leydig cells $48 \mathrm{~h}$ after treatment.

AM treatment increased Leydig cell testosterone production To determine potential effects of $A M$ on the production of testosterone in Leydig cells, cells were treated with increasing concentrations of $A M$. Significantly higher concentrations $(P<0.01)$ of testosterone were observed in culture media of cells treated with $20 \mu \mathrm{g} / \mathrm{mL}, 50 \mu \mathrm{g} / \mathrm{mL}$, and $100 \mu \mathrm{g} / \mathrm{mL}$ of $A M$ injection for $48 \mathrm{~h}$ (compared with untreated control; Fig. 3), suggesting certain stimulatory effects of $A M$ injection on Leydig cell testosterone production. Intra- assay and inter- assay coefficients of variation were $<11 \%$ and $<9 \%$, respectively.

$A M$ injection treatment increased $S O D$ and GPx activities To determine the effect of $A M$ on the antioxidant defense system, the activities of SOD and GPx were detected in cultured Leydig cells $48 \mathrm{~h}$ after $A M$ treatment. As shown in Fig. 4, the activities of SOD and GPx were significantly increased in Leydig cell cultures treated

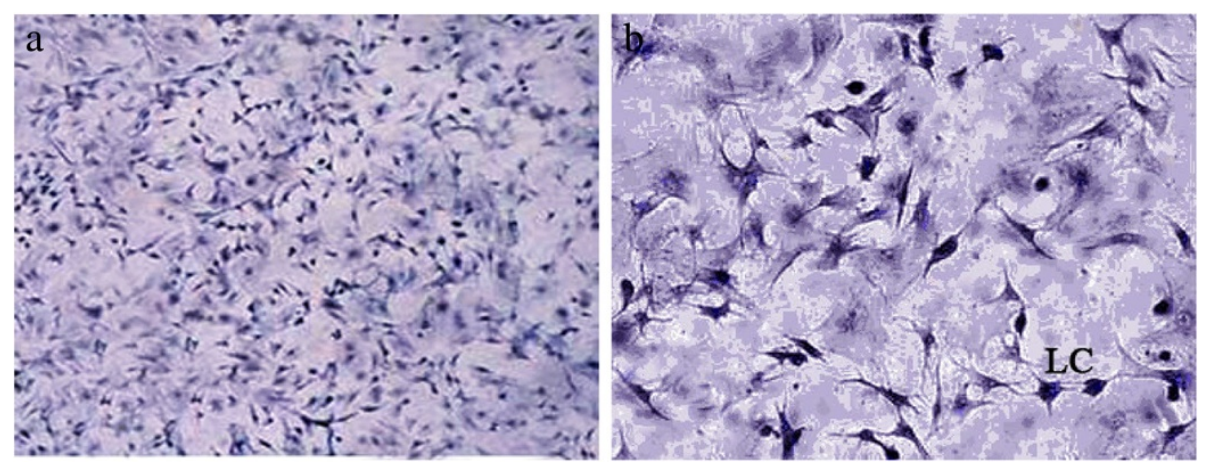

Fig. $13 \beta-H S D$ staining of Leydig cells. a Magnification, 100x; b Magnification, 400x. LC, Leydig cell 


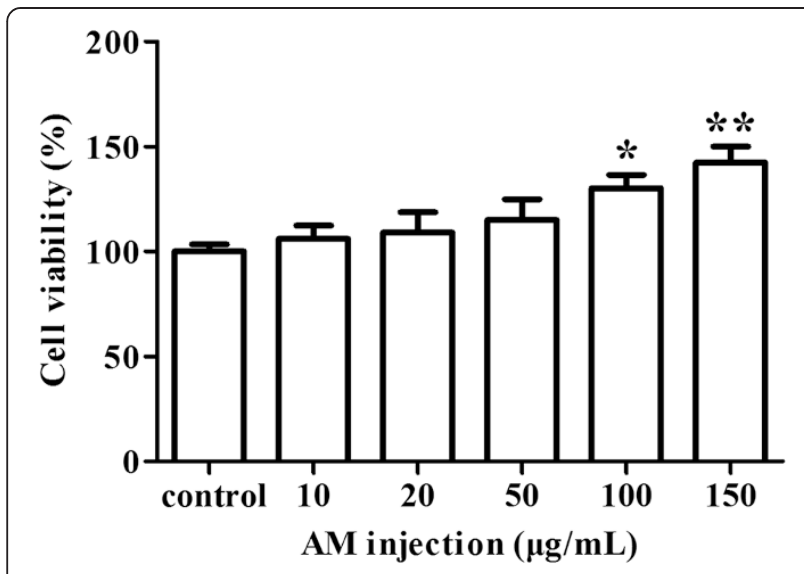

Fig. 2 Effect of $A M$ treatment on viable Leydig cell numbers. Cells were treated with $0 \mu \mathrm{g} / \mathrm{mL}, 10 \mu \mathrm{g} / \mathrm{mL}, 20 \mu \mathrm{g} / \mathrm{mL}, 50 \mu \mathrm{g} / \mathrm{mL}, 100 \mu \mathrm{g} / \mathrm{mL}$ and $150 \mu \mathrm{g} / \mathrm{mL}$ of $A M$. Cell viability was analyzed by CCK-8 assay. Results are depicted as mean $+/-\mathrm{SE}^{*} P<0.05,{ }^{*} P<0.01$

with $20 \mu \mathrm{g} / \mathrm{mL}$ and $50 \mu \mathrm{g} / \mathrm{mL}$ of $A M$ relative to untreated controls $(P<0.01)$. Results indicated $A M$ treatment could increase Leydig cell antioxidant activity within a certain range of concentration.

Effect of AM on Bax and Bcl-2 mRNA expression in $A M$ treated Leydig cells To further elucidate the potential effects of $A M$ on Leydig cell numbers, the expression of apoptosis-related genes $\mathrm{Bax}$ and $\mathrm{Bcl}-2$ in Leydig cells treated with $0 \mu \mathrm{g} / \mathrm{mL}$ or $20 \mu \mathrm{g} / \mathrm{mL}$ of $A M$ injection for 48 $\mathrm{h}$ were analyzed using qRT-PCR. Results showed in Fig. 5 indicated the expression of $B a x$ mRNA was significantly reduced in $A M$ treated group $(P<0.01)$ compared with the untreated control, while the expression of $\mathrm{Bcl}-2$ mRNA had no obvious change between $A M$ treated group and the untreated control $(P>0.05)$. However, the ratio of

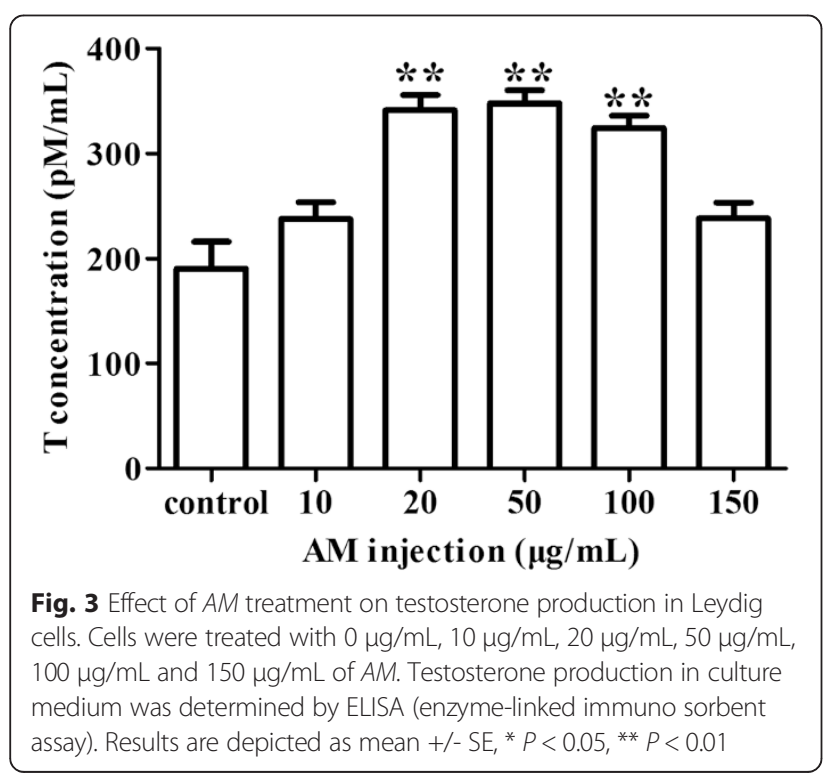

$B c l-2 / B a x$ mRNA was significantly higher in the $A M$ treated group versus the untreated control $(P<0.05)$.

\section{Discussion}

Many studies have suggested a positive role for $A M$ in the treatment of various diseases. In the present study, we investigated the effect of $A M$ injection on function of rat Leydig cells. According to the instructions for $A M$ injection and relevant reference [21], we at first used $A M$ concentrations that ranged from $0-80 \mu \mathrm{g} / \mathrm{mL}$ to take the preliminary test. The result showed that there was no significant difference in cell number among these concentrations (the result was not provided). After several times of preliminary test and adjusting the concentration gradient, finally we chose $0 \mu \mathrm{g} / \mathrm{mL}, 10 \mu \mathrm{g} / \mathrm{mL}, 20 \mu \mathrm{g} / \mathrm{mL}$, $50 \mu \mathrm{g} / \mathrm{mL}, 100 \mu \mathrm{g} / \mathrm{mL}, 150 \mu \mathrm{g} / \mathrm{mL}$ as the test concentration gradient.

Several studies have reported stimulatory effects of Astragaloside (main compound extracted from $A M$ ) $[4,22]$ on cell proliferation, which was also observed in this study. Leydig cells influence sexual maturation of males by secreting testosterone, which is influenced by cell number and rate of steroidogenesis. However, significant changes in cell proliferation and testosterone production did not occur at the same dosage of $A M$. The increase in testosterone production occurred at lower concentrations of $A M$ than those demonstrated to increase Leydig cell numbers. Results suggested direct effects of $A M$ on regulation of steroidogenesis independent of modulation of cell numbers.

Apoptosis is regulated by various factors, among which pro- and anti-apoptotic proteins of $\mathrm{Bcl}-2$ family play an important role. Relative to the absolute expression of either gene alone, the ratio of $B c l-2$ to $B a x$ is regarded as a better determinant to measure cell survival [23]. In the present study, we found significantly decreased $\mathrm{Bax}$ expression in the $A M$ treated Leydig cells, which is consistent with a previous study demonstrating similar effects of $A M$ on Bax expression in skin [11]. However, $A M$ treatment did not increase Leydig cell $B c l-2$ expression in the current studies. Therefore, the increased ratio of $\mathrm{Bcl}-2$ / $B a x$ in $A M$ treated group may be attributed to the inhibitory effect of $A M$ on $B a x$ mRNA. A previous study demonstrated that intravenous injection of Astragaloside down-regulated Bax mRNA to reduce apoptosis in a rodent acute kidney injury model [3].

SOD catalyzes the dismutation of the superoxide anion, and GPx mediates the breakdown of hydrogen peroxide. These enzymes, as well as other antioxidant enzymes, are the main components of antioxidant defense system that possesses high potency to scavenge reactive oxygen species free radicals that are detrimental to cell survival by affecting cellular signaling pathways and gene expression. In the present study, we detected increased activities of SOD and GPx in the $A M$ treated Leydig cells, supporting the 

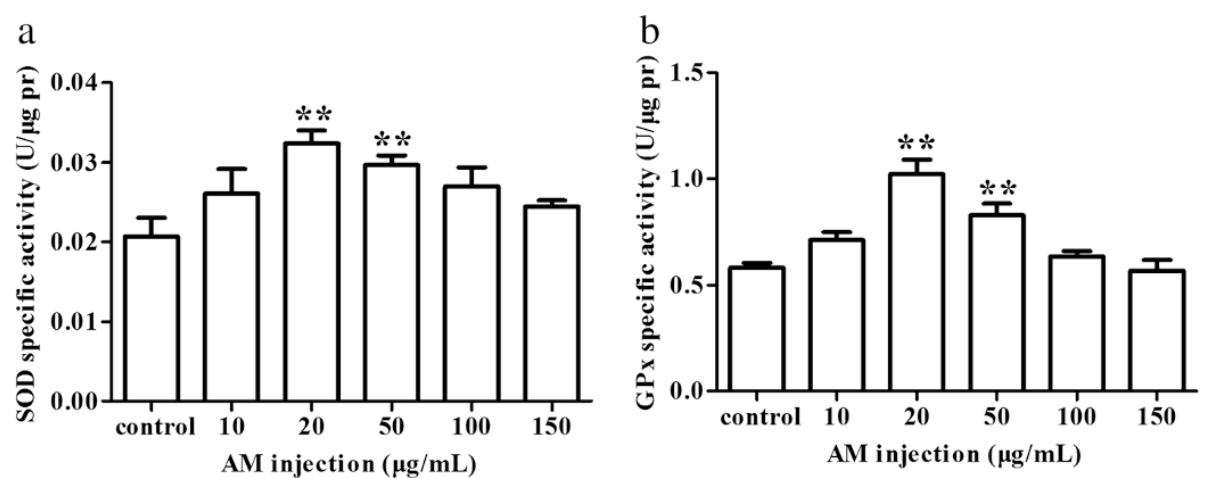

Fig. 4 Effect of $A M$ treatment on the activities of SOD and GPx in Leydig cells. Cells were treated with $0 \mu \mathrm{g} / \mathrm{mL}, 10 \mu \mathrm{g} / \mathrm{mL}, 20 \mu \mathrm{g} / \mathrm{mL}, 50 \mu \mathrm{g} / \mathrm{mL}$, $100 \mu \mathrm{g} / \mathrm{mL}$ and $150 \mu \mathrm{g} / \mathrm{mL}$ of $A M$. a SOD activity. $\mathbf{b}$ GPx activity. Results are depicted as mean $+/-\mathrm{SE}^{*} P<0.05,{ }^{* *} P<0.01$

antioxidant role of $A M$. Previous studies linked the therapeutic effects of $A M$ on myocardial ischemia [24], ischemic brain injury [25], hemorrhagic shock-reperfusion injury of intestinal mucosa [26] and the epithelial-tomesenchymal transition in diabetic kidney disease [21] to increased activities of antioxidant enzymes such as GPx and SOD. A large body of evidence indicates antioxidants can suppress apoptosis. Hence, it is plausible that the increase in Leydig cell numbers is linked, at least in part, to stimulatory effects of $A M$ on SOD and GPx activity resulting in reduced apoptotic cell death.

Cell proliferation is a process regulated by lots of factors. The SOD and GPx activity was just one aspect that could be considered to evaluate the growth of Leydig cells. Perhaps $A M$ at the concentrations of $20 \mu \mathrm{g} / \mathrm{mL}$ and $50 \mu \mathrm{g} / \mathrm{mL}$ was optimal for the SOD and GPx activity of Leydig cells although it had no obvious promotion for cell proliferation. With the increase of concentration, the amount of $A M$ was too much for the SOD and GPx, so the activity decreased, but the number of Leydig cells was significantly increased in the process. Perhaps all above lead to the result that the treated group in which there was a significant difference of Leydig cell number was not consistent with that of SOD and GPx activity. Results suggested direct effects of $A M$ on regulation of SOD and GPx activity independent of modulation of cell numbers.

Although the study preliminarily indicated that $A M$ injection has a stimulatory effect on multiple aspects of rat Leydig cell function in vitro, it had some limitations, such as the design of $A M$ injection gradient, and this was just the results of cell culture level. Therefore, lots of work and study should be done to elucidate the exact mechanism of $A M$ promoting the function of Leydig cells.

\section{Conclusions}

In the present study, we investigated the influence of $A M$ injection on cell numbers and testosterone production of rat Leydig cells cultured in vitro. The results suggested that $A M$ injection has a favorable effect on the function of Leydig cells. The study provides a foundation for future studies to understand the mechanisms responsible for stimulatory effects of $A M$ injection on Leydig cells and whether $A M$ treatment in vivo can enhance indices of male fertility.

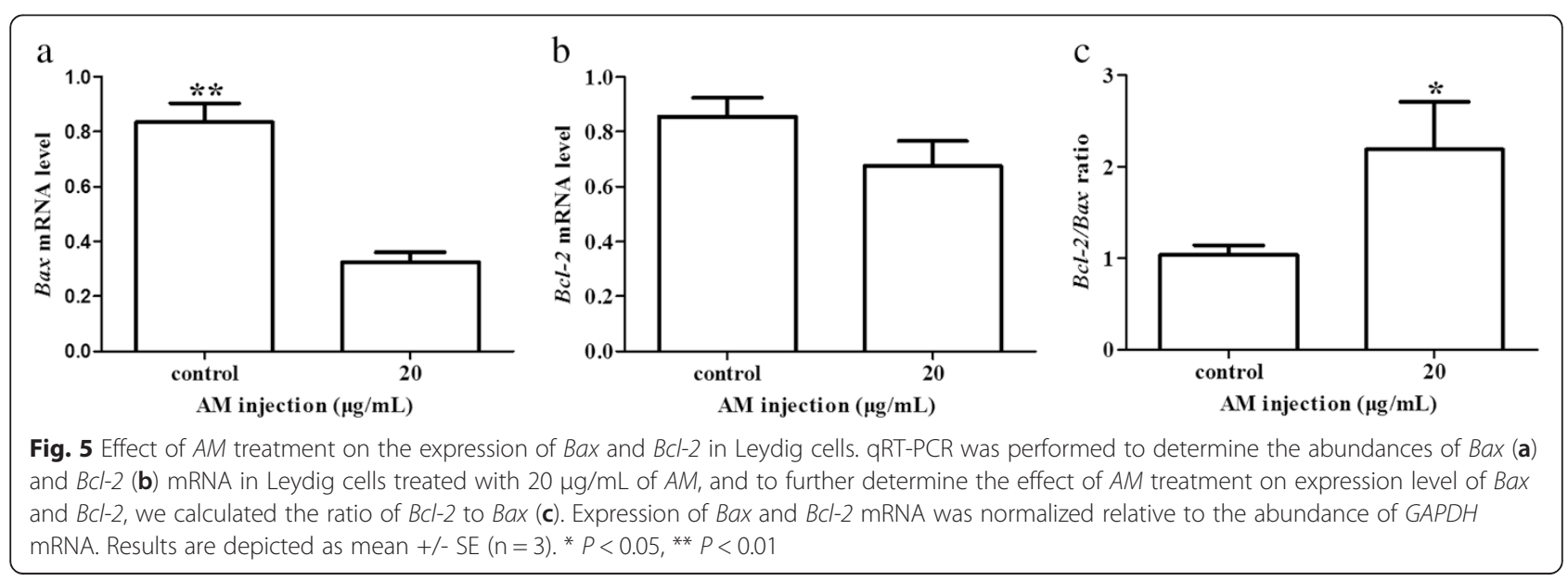




\section{Competing interests}

The authors declare that they have no competing interests.

\section{Authors' contributions}

$\mathrm{XLJ}$ performed the statistical analyses and drafted the manuscript. XC participated in the design of the study and carried out the assays. XLY, JWC and MMZ assisted in the cell culture assays. YL and JZM assisted in the Quantitative real time PCR and ELSIA. ZYL participated in the design of the study and provided technical supports. YH and PFL participated in the statistical analyses and assisted in drafting the manuscript. JBY, GS and LHL provided conceptual advice and critically revised the manuscript. All authors read and approved the final manuscript.

\section{Acknowledgements}

This study was Supported by Chinese Natural Science Foundation (No. 31172211), Shanxi Scholarship Council of China (2014-key 5), and Shanxi Talent Introduction Project and SXAU Research Achievement Development Project(71060003).

\section{Author details}

${ }^{1}$ College of Animal Science and Technology, Shanxi Agricultural University, No.1 Mingxian Nan Road, Taigu 030801, China. ${ }^{2}$ College of Life Science, Shanxi Agricultural University, Taigu, Shanxi 030801, China. ${ }^{3}$ Pharmaceutical Analysis Laboratory of Fudan University, Shanghai 200000, China. ${ }^{4}$ Laboratory of Mammalian Reproductive Biology and Genomics, Michigan State University, East Lansing, MI 48824, USA. ${ }^{5}$ Departments of Animal Science, Michigan State University, East Lansing, MI 48824, USA. ${ }^{6}$ Departments of Animal Physiology, Michigan State University, East Lansing, MI 48824, USA. ${ }^{7}$ Division of Animal and Nutritional Sciences, West Virginia University, Morgantown, WV 26506, USA.

Received: 25 March 2015 Accepted: 13 July 2015

Published online: 01 August 2015

\section{References}

1. Rato L, Alves MG, Socorro S, Duarte Al, Cavaco JE, Oliveira PF. Metabolic regulation is important for spermatogenesis. Nat Rev Urol. 2012;9:330-8.

2. Zhang YW, Wu CY, Cheng JT. Merit of Astragalus polysaccharide in the improvement of early diabetic nephropathy with an effect on mRNA expressions of NF-kappaB and IkappaB in renal cortex of streptozotoxin-induced diabetic rats. J Ethnopharmacol. 2007;114:387-92.

3. Gui D, Huang J, Guo Y, Chen J, Chen Y, Xiao W, et al. Astragaloside IV ameliorates renal injury in streptozotocin-induced diabetic rats through inhibiting NF-kappaB-mediated inflammatory genes expression. Cytokine. 2013;61:970-7.

4. Zhang Y, Hu G, Li S, Li ZH, Lam CO, Hong SJ, et al. Pro-angiogenic activity of astragaloside IV in HUVECs in vitro and zebrafish in vivo. Mol Med Rep. 2012:5:805-11

5. Zhang L, Liu Q, Lu L, Zhao X, Gao X, Wang Y. Astragaloside IV stimulates angiogenesis and increases hypoxia-inducible factor-1alpha accumulation via phosphatidylinositol 3-kinase/Akt pathway. J Pharmacol Exp Ther. 2011;338:485-91.

6. Kim BH, Oh I, Kim JH, Jeon JE, Jeon B, Shin J, et al. Anti-inflammatory activity of compounds isolated from Astragalus sinicus L. in cytokineinduced keratinocytes and skin. Exp Mol Med. 2014;46:e87.

7. Gao J, Feng L, Huang Y, Li P, Xu DJ, Li J, et al. Total glucosides of Danggui Buxue Tang attenuates bleomycin-induced pulmonary fibrosis via inhibition of extracellular matrix remodelling. J Pharm Pharmacol. 2012;64:811-20.

8. Li Z, Zhang L, He W, Zhu C, Yang J, Sheng M. Astragalus membranaceus inhibits peritoneal fibrosis via monocyte chemoattractant protein (MCP)-1 and the transforming growth factor-beta1 (TGF-beta1) pathway in rats submitted to peritoneal dialysis. Int J Mol Sci. 2014;15:12959-71.

9. Wei MG, Sun W, Xiong PH, Shao JD. Antifibrotic effect of the Chinese herbs Modified Danggui Buxue Decoction on adriamycin-induced nephropathy in rats. Chin J Integr Med. 2012;18:591-8.

10. He Y, Du M, Gao Y, Liu H, Wang H, Wu X, et al. Astragaloside IV attenuates experimental autoimmune encephalomyelitis of mice by counteracting oxidative stress at multiple levels. PLoS ONE. 2013;8:e76495.

11. Kim MH, Kim SH, Yang WM. Beneficial effects of Astragaloside IV for hair loss via inhibition of Fas/Fas L-mediated apoptotic signaling. PLOS ONE. 2014;9:e92984.
12. Wang B, Chen MZ. Astragaloside IV possesses antiarthritic effect by preventing interleukin 1 beta-induced joint inflammation and cartilage damage. Arch Pharm Res. 2014;37:793-802.

13. Hong F, Xiao W, Ragupathi G, Lau CB, Leung PC, Yeung KS, et al. The known immunologically active components of Astragalus account for only a small proportion of the immunological adjuvant activity when combined with conjugate vaccines. Planta Med. 2011;77:817-24.

14. Botchkareva NV, Ahluwalia G, Shander D. Apoptosis in the hair follicle. J Invest Dermatol. 2006;126:258-64.

15. Gui D, Guo Y, Wang F, Liu W, Chen J, Chen Y, et al. Astragaloside IV, a novel antioxidant, prevents glucose-induced podocyte apoptosis in vitro and in vivo. PLOS ONE. 2012;7:e39824.

16. Hong CY, Ku J, Wu P. Astragalus membranaceus stimulates human sperm motility in vitro. Am J Chin Med. 1992;20:289-94.

17. Kim W, Kim SH, Park SK, Chang MS. Astragalus membranaceus ameliorates reproductive toxicity induced by cyclophosphamide in male mice. Phytother Res. 2012;26:1418-21.

18. Liang P, Li H, Peng X, Xiao J, Liu J, Ye Z. [Effects of astragalus membranaceus injection on sperm abnormality in Cd-induced rats]. Zhonghua Nan Ke Xue. 2004;10:42-5. 48.

19. Chen H, Ge RS, Zirkin BR. Leydig cells: from stem cells to aging. Mol Cell Endocrinol. 2009;306:9-16.

20. Shi L, Zhao H, Ren Y, Yao X, Song R, Yue W. Effects of different levels of dietary selenium on the proliferation of spermatogonial stem cells and antioxidant status in testis of roosters. Anim Reprod Sci. 2014;149:266-72.

21. Qi W, Niu J, Qin Q, Qiao Z, Gu Y. Astragaloside IV attenuates glycated albumin-induced epithelial-to-mesenchymal transition by inhibiting oxidative stress in renal proximal tubular cells. Cell Stress Chaperones. 2014;19:105-14.

22. Junior AA, Oliveira LS, Assis Neto AC, Alves FR, Miglino MA, Carvalho MA. Spermatogenesis in goats with and without scrotum bipartition. Anim Reprod Sci. 2012;130:42-50

23. Tanaka K, Asanuma M, Ogawa N. Molecular basis of anti-apoptotic effect of immunophilin ligands on hydrogen peroxide-induced apoptosis in human glioma cells. Neurochem Res. 2004;29:1529-36.

24. Zhang WD, Chen H, Zhang C, Liu RH, Li HL, Chen HZ. Astragaloside IV from Astragalus membranaceus shows cardioprotection during myocardial ischemia in vivo and in vitro. Planta Med. 2006;72:4-8.

25. Luo Y, Qin Z, Hong Z, Zhang X, Ding D, Fu JH, et al. Astragaloside IV protects against ischemic brain injury in a murine model of transient focal ischemia. Neurosci Lett. 2004;363:218-23.

26. Hei ZQ, Huang HQ, Zhang JJ, Chen BX, Li XY. Protective effect of Astragalus membranaceus on intestinal mucosa reperfusion injury after hemorrhagic shock in rats. World J Gastroenterol. 2005;11:4986-91.

\section{Submit your next manuscript to BioMed Central and take full advantage of:}

- Convenient online submission

- Thorough peer review

- No space constraints or color figure charges

- Immediate publication on acceptance

- Inclusion in PubMed, CAS, Scopus and Google Scholar

- Research which is freely available for redistribution 